\title{
MODELLING ANIMAL SYSTEMS PAPER
}

\section{Application of the law of diminishing returns to estimate maintenance requirement for amino acids and their efficiency of utilization for accretion in young chicks}

\author{
H. DARMANI KUHI ${ }^{1}$, E. KEBREAB ${ }^{2 *}$, S. LOPEZ ${ }^{3}$ AND J. FRANCE ${ }^{4}$ \\ ${ }^{1}$ Animal Sciences Group, Faculty of Agriculture, University of Ilam, Ilam 69315/516, Iran \\ ${ }^{2}$ National Centre for Livestock and Environment, Department of Animal Science, University of Manitoba, \\ Winnipeg, $M B$, R3T 2N2, Canada \\ ${ }^{3}$ Departamento de Producción Animal, Universidad de León, E-24007 León, Spain \\ ${ }^{4}$ Centre for Nutrition Modelling, Department of Animal and Poultry Science, University of Guelph, Guelph, \\ ON, N1G 2W1, Canada
}

(Revised MS received 4 December 2008; First published online 16 February 2009)

\begin{abstract}
SUMMARY
Suitability of the monomolecular equation, specifically re-parameterized for analysing energy balance data, has recently been investigated in broilers and turkeys. In the current study, this equation was applied to literature data from growing chicks fed crystalline amino acid (AA) diets, in order to provide estimates for AA requirements for maintenance, body-weight gain and protein accretion. Non-linear regression was used with the data to estimate parameters and combine them to determine other biological indicators. The predictive ability of the model was evaluated with reference to model behaviour when fitting the data, biologically meaningful parameter estimates and statistical performance. The model estimated the maintenance requirements for valine, threonine and lysine to be in the range $80-111,96-109$ and $52-209 \mathrm{mg} / \mathrm{kg}$ of liveweight/day, respectively, depending on the response criterion. Requirements for maintenance were in good agreement with values reported previously. Average efficiency of recovering AAs in whole body protein, between maintenance and four $\times$ maintenance, was in the reported range of $0 \cdot 80-1 \cdot 0$ and greatest at low intakes and decreasing as intakes increase.
\end{abstract}

\section{INTRODUCTION}

Essential amino acid (AA) requirements for broiler chickens are well documented, but for practical prediction of performance, difficulty remains in deciding the most advantageous dietary AA patterns to use. This difficulty is partly due to non-linearity of the growth response to change in dietary AA concentrations (Gous \& Morris 1985; Oviedo-Rondón \& Waldroup 2002). To develop accurate models of AA requirements, estimates of maintenance requirements and efficiencies of utilizing indispensable AAs for whole body protein accretion are essential (Edwards $\&$ Baker 1999). There are models for predicting the

* To whom all correspondence should be addressed. Email: kebreabe@cc.umanitoba.ca
AA requirements of poultry. Curnow (1973) introduced a smooth population curve to describe egg production based on a broken-stick assumption and information about the standard deviations of body weight (BW) and egg output. The model was used by Fisher et al. (1973) for laying hens and Boorman \& Burgess (1986) for growing chickens to estimate AA requirements. Researchers at Edinburgh (e.g. Emmans 1981) proposed a programme that utilizes projected Gompertz growth curves to partition energy and protein intake of broilers between daily maintenance requirement, protein and feather growth. Hurwitz et al. (1978) constructed a model to estimate protein and AA requirements of broilers for maintenance and growth. The model was later modified to take into account effects of environmental temperature and differences in composition of weight gain 
(proportion of lipid) on energy needs in both chickens and turkeys (Hurwitz et al. 1983). National Research Council (NRC) (1994a) accepted this model as a good estimator of requirements for some AAs for which no experimental results were available. However, the model of Hurwitz et al. (1978) is founded on the premise that growth rate determines requirements based on some fixed rate of nutrient utilization, which does not represent adequately the biological phenomena involved (Pesti \& Miller 1997). There are numerous studies suggesting that a limiting $\mathrm{AA}$ is utilized with constant efficiency over the range of intakes from maintenance to that required for maximal protein accretion (e.g. Hurwitz et al. 1978, 1983; Baker 1991; Baker et al. 1996; Edwards et al. 1997, 1999; Edwards \& Baker 1999). In contrast, Heger \& Frydrych (1985), Gahl et al. (1994), Vazquez \& Pesti (1997), Baker et al. (2002) and Fatufe et al. (2004, 2005), demonstrated that efficiency of utilization of AAs declined as their intake approached optimum.

Non-linear models have been used to estimate AA requirements. For example, Samadi \& Liebert $(2007 a, b)$ used an exponential function relating $\mathrm{N}$ intake to $\mathrm{N}$ retention and calculated lysine and threonine requirements in growing chicks. The potential and validity of a specially re-parameterized monomolecular model (Darmani Kuhi et al. 2001) to partition AA intakes between requirements for maintenance and growth have been demonstrated recently in relation to broilers using results from two types of study, namely bioassay and nitrogen balance experiments (Kebreab et al. 2008). The present study aims to apply this model to provide estimates of AA requirement for maintenance and efficiency of utilization of dietary AA for live weight gain (LWG), protein and AA accretion using the results of four studies (Baker et al. 1996; Edwards et al. 1997, 1999).

\section{MATERIALS AND METHODS}

\section{Experimental data}

Results of four bioassays, conducted to determine maintenance requirement and efficiency of utilization of dietary AA in young chicks, taken from the literature for slow and fast growing broiler strains, were used in the current study (Baker et al. 1996; Edwards et al. 1997, 1999). In each assay, chicks were given free access to crystalline AA diets containing graded levels of AA to meet ideal levels of indispensable AA requirements (Table 1).

\section{The model}

The suitability of the monomolecular equation (Eqn 1), specifically re-parameterized for analysing energy balance data, in relation to broilers and turkeys has been investigated recently (Darmani Kuhi et al. 2001, 2003, 2004; Kebreab et al. 2008). In the current study, this equation was used to provide estimates of AA requirements for maintenance, gain and protein (or AA) accretion in fast and slow growing broilers:

$$
y=y_{\max }\left[1-\mathrm{e}^{-K\left(x-x_{m}\right)}\right] \quad x \geqslant 0
$$

where $y$ is $\mathrm{BW}$ gain (BWG) or protein (or AA) accretion [ $\mathrm{g}$ of BWG or $\mathrm{g}$ of protein (or $\mathrm{mg}$ of $\mathrm{AA}$ ) accretion/g of $\mathrm{BW} / \mathrm{d}], y_{\max }$ is the theoretical maximum attainable value for $y, K$ is a fractional rate parameter [mg of AA intake/g of $\mathrm{BW} / \mathrm{d}]^{-1}, x$ is AA intake $[\mathrm{mg}$ of $\mathrm{AA} / \mathrm{g}$ of $\mathrm{BW} / \mathrm{d}]$ and $x_{m}$ is AA intake at maintenance. The model was fitted to the data and the parameters and AA requirements for maintenance estimated. The average efficiency of utilization between $\Delta_{1} \times$ maintenance and $\Delta_{2} \times$ maintenance $\left(\Delta_{2}\right.$ $\left.\geqslant \Delta_{1} \geqslant 1\right)$ is determined by

$$
\begin{gathered}
\bar{k}_{g}\left(\Delta_{1}, \Delta_{2}\right)=\frac{y\left(\Delta_{2} x_{m}\right)-y\left(\Delta_{1} x_{m}\right)}{\left(\Delta_{2}-\Delta_{1}\right) x_{m}} \\
\text { Statistical procedures }
\end{gathered}
$$

Due to the absence of a single robust criterion for model evaluation, three criteria were used to evaluate model adequacy: (1) model behaviour when fitting the curves using non-linear regression, (2) statistical performance and (3) comparison of biologically meaningful indicators obtained using the model. All statistical analyses were performed using the nonlinear function of SigmaPlot (SPSS 1998). The proportion of variation accounted for $\left(R^{2}\right)$, the amount of total variation about the mean value of $y$ explained by the fitted curves, was used as a measure of adequacy of the model.

\section{RESULTS}

Figure 1 shows the fit of the model to the data on BWG (or protein (or AA) accretion) v. AA intake. The resultant curves (Fig. 1) and general goodness of fit, based on variation accounted for $\left(R^{2}\right)$ and standard error (s.E.) estimated for the growth parameters, indicated that fits of the model to the data sets were acceptable (Table 2). The curves shown in Fig. 1 were extrapolated to the $y$-axis, so that $x$ at $y$ zero (which represents the AA requirement for maintenance) can be computed. Estimates of maintenance AA requirements for zero BWG, zero protein accretion and zero AA accretion were then calculated (Table 2). The maintenance requirements estimated by the model were in the range of $80-111,96-109$ and $52-209 \mathrm{mg} /$ $\mathrm{kg}$ of live weight $(\mathrm{LW}) /$ day for valine, threonine and lysine, respectively, depending on the response criterion. The results giving higher maintenance requirements of AA using zero AA accretion are in agreement with the results of Baker et al. (1996) and 
Table 1. Accretion of body-weight $(\Delta W)$, protein, and AA in chicks fed graded levels of valine, threonine and lysine

Baker et al. (1996), Avian $\times$ Avian males*

\begin{tabular}{|c|c|c|c|c|c|c|}
\hline \multicolumn{2}{|c|}{ Dietary valine } & \multicolumn{2}{|c|}{ Intake } & \multicolumn{3}{|c|}{ Accretion } \\
\hline $\begin{array}{l}\text { Level } \\
\text { ( } \mathrm{g} / \mathrm{kg} \text { of diet) }\end{array}$ & $\begin{array}{c}\text { Proportion } \\
\text { of ideal }\end{array}$ & $\begin{array}{l}\text { Diet } \\
(\mathrm{g} / \mathrm{d})\end{array}$ & $\begin{array}{l}\text { Valine } \\
(\mathrm{mg} / \mathrm{d})\end{array}$ & $\begin{array}{c}\Delta W \\
(\mathrm{~g} / \mathrm{d})\end{array}$ & $\begin{array}{l}\text { Protein } \\
(\mathrm{g} / \mathrm{d})\end{array}$ & $\begin{array}{l}\text { Valine } \\
(\mathrm{mg} / \mathrm{d})\end{array}$ \\
\hline $0 \cdot 35$ & $0 \cdot 05$ & $19 \cdot 2$ & $6 \cdot 7$ & $-1 \cdot 2$ & $-0 \cdot 10$ & $-8 \cdot 7$ \\
\hline 0.69 & $0 \cdot 10$ & $22 \cdot 4$ & $15 \cdot 5$ & $0 \cdot 4$ & $0 \cdot 02$ & $-2 \cdot 4$ \\
\hline $2 \cdot 77$ & $0 \cdot 40$ & $32 \cdot 8$ & $90 \cdot 9$ & $8 \cdot 2$ & $1 \cdot 30$ & $53 \cdot 1$ \\
\hline $3 \cdot 81$ & $0 \cdot 55$ & $42 \cdot 2$ & $160 \cdot 8$ & $14 \cdot 3$ & $2 \cdot 13$ & 100 \\
\hline $4 \cdot 85$ & $0 \cdot 70$ & $41 \cdot 8$ & $202 \cdot 6$ & $18 \cdot 4$ & $3 \cdot 14$ & $139 \cdot 6$ \\
\hline 0.658 & 0.95 & 42 & $276 \cdot 2$ & $22 \cdot 8$ & $4 \cdot 02$ & $190 \cdot 1$ \\
\hline
\end{tabular}

Edwards et al. (1997), Avian $\times$ Avian males $\uparrow$

\begin{tabular}{|c|c|c|c|c|c|c|}
\hline \multicolumn{2}{|c|}{ Dietary Threonine } & \multicolumn{2}{|c|}{ Intake } & \multicolumn{3}{|c|}{ Accretion } \\
\hline $\begin{array}{l}\text { Level } \\
\text { (g/kg of diet) }\end{array}$ & $\begin{array}{c}\text { Proportion } \\
\text { of ideal }\end{array}$ & $\begin{array}{l}\text { Diet } \\
(\mathrm{g} / \mathrm{d})\end{array}$ & $\begin{array}{l}\text { Threonine } \\
(\mathrm{mg} / \mathrm{d})\end{array}$ & $\begin{array}{c}\Delta W \\
(\mathrm{~g} / \mathrm{d})\end{array}$ & $\begin{array}{l}\text { Protein } \\
(\mathrm{g} / \mathrm{d})\end{array}$ & $\begin{array}{c}\text { Threonine } \\
(\mathrm{mg} / \mathrm{d})\end{array}$ \\
\hline $3 \cdot 00$ & 0.05 & $15 \cdot 4$ & $4 \cdot 6$ & $-1 \cdot 20$ & -0.23 & $-11 \cdot 9$ \\
\hline $6 \cdot 00$ & $0 \cdot 10$ & $16 \cdot 5$ & $9 \cdot 9$ & -0.83 & $-0 \cdot 11$ & $-6 \cdot 4$ \\
\hline $9 \cdot 00$ & $0 \cdot 15$ & $16 \cdot 7$ & $15 \cdot 1$ & $-0 \cdot 38$ & $0 \cdot 00$ & $-2 \cdot 3$ \\
\hline $24 \cdot 1$ & $0 \cdot 40$ & $25 \cdot 8$ & $62 \cdot 3$ & $5 \cdot 88$ & 0.97 & $40 \cdot 0$ \\
\hline $33 \cdot 2$ & 0.55 & $34 \cdot 7$ & $115 \cdot 2$ & $11 \cdot 70$ & 1.94 & $83 \cdot 2$ \\
\hline $42 \cdot 2$ & $0 \cdot 70$ & $36 \cdot 7$ & $154 \cdot 7$ & $15 \cdot 25$ & $2 \cdot 67$ & $116 \cdot 9$ \\
\hline $57 \cdot 3$ & 0.95 & $37 \cdot 3$ & $213 \cdot 6$ & $20 \cdot 92$ & $3 \cdot 62$ & $158 \cdot 37$ \\
\hline
\end{tabular}

Edwards et al. (1999), assay 1, New Hampshire $\times$ Columbian malesł

\begin{tabular}{|c|c|c|c|c|c|c|}
\hline \multicolumn{2}{|c|}{ Dietary lysine } & \multicolumn{2}{|c|}{ Intake } & \multicolumn{3}{|c|}{ Accretion } \\
\hline $\begin{array}{l}\text { Level } \\
\text { (g/kg of diet) }\end{array}$ & $\begin{array}{c}\text { Proportion } \\
\text { of ideal }\end{array}$ & $\begin{array}{l}\text { Diet } \\
(\mathrm{g} / \mathrm{d})\end{array}$ & $\begin{array}{l}\text { Lysine } \\
(\mathrm{mg} / \mathrm{d})\end{array}$ & $\begin{array}{c}\Delta W \\
(\mathrm{~g} / \mathrm{d})\end{array}$ & $\begin{array}{l}\text { Protein } \\
(\mathrm{g} / \mathrm{d})\end{array}$ & $\begin{array}{l}\text { Lysine } \\
(\mathrm{mg} / \mathrm{d})\end{array}$ \\
\hline $0 \cdot 45$ & 0.05 & $15 \cdot 3$ & $6 \cdot 9$ & $0 \cdot 0$ & $0 \cdot 0$ & $-20 \cdot 9$ \\
\hline $3 \cdot 60$ & $0 \cdot 40$ & $15 \cdot 0$ & $54 \cdot 2$ & $3 \cdot 0$ & $0 \cdot 3$ & $15 \cdot 1$ \\
\hline $4 \cdot 95$ & $0 \cdot 55$ & $19 \cdot 6$ & $96 \cdot 9$ & $6 \cdot 2$ & $1 \cdot 1$ & $50 \cdot 5$ \\
\hline $6 \cdot 30$ & $0 \cdot 70$ & $22 \cdot 7$ & $143 \cdot 1$ & $10 \cdot 1$ & $1 \cdot 8$ & $100 \cdot 9$ \\
\hline $8 \cdot 55$ & $0 \cdot 95$ & $30 \cdot 4$ & $260 \cdot 0$ & $14 \cdot 6$ & $2 \cdot 9$ & $167 \cdot 2$ \\
\hline
\end{tabular}

Edwards et al. (1999), assay 2, Avian $\times$ Avian malesł

\begin{tabular}{|c|c|c|c|c|c|c|}
\hline \multicolumn{2}{|c|}{ Dietary lysine } & \multicolumn{2}{|c|}{ Intake } & \multicolumn{3}{|c|}{ Accretion } \\
\hline $\begin{array}{l}\text { Level } \\
\text { (g/kg of diet) }\end{array}$ & $\begin{array}{c}\text { Proportion } \\
\text { of ideal }\end{array}$ & $\begin{array}{l}\text { Diet } \\
(\mathrm{g} / \mathrm{d})\end{array}$ & $\begin{array}{l}\text { Lysine } \\
(\mathrm{mg} / \mathrm{d})\end{array}$ & $\begin{array}{c}\Delta W \\
(\mathrm{~g} / \mathrm{d})\end{array}$ & $\begin{array}{l}\text { Protein } \\
(\mathrm{g} / \mathrm{d})\end{array}$ & $\begin{array}{l}\text { Lysine } \\
(\mathrm{mg} / \mathrm{d})\end{array}$ \\
\hline $0 \cdot 45$ & $0 \cdot 05$ & $18 \cdot 2$ & $8 \cdot 2$ & $-0 \cdot 12$ & $0 \cdot 01$ & -20 \\
\hline $0 \cdot 90$ & $0 \cdot 10$ & $22 \cdot 1$ & $19 \cdot 9$ & 1.07 & $0 \cdot 17$ & $-8 \cdot 4$ \\
\hline $3 \cdot 60$ & $0 \cdot 40$ & $33 \cdot 2$ & $119 \cdot 4$ & $9 \cdot 35$ & $1 \cdot 46$ & $74 \cdot 7$ \\
\hline $4 \cdot 95$ & 0.55 & $37 \cdot 4$ & $185 \cdot 3$ & $14 \cdot 27$ & $2 \cdot 19$ & $118 \cdot 5$ \\
\hline $6 \cdot 35$ & $0 \cdot 70$ & $43 \cdot 0$ & $270 \cdot 9$ & $17 \cdot 35$ & $3 \cdot 01$ & $181 \cdot 7$ \\
\hline $8 \cdot 55$ & 0.95 & $39 \cdot 6$ & $338 \cdot 2$ & $20 \cdot 45$ & $3 \cdot 88$ & $247 \cdot 1$ \\
\hline
\end{tabular}

* Data are means of four pens of four chicks during a 10-d assay (10-20 post-hatching). Average initial weight was $158 \mathrm{~g}$. $\dagger$ Data are means of four pens of four chicks during a 10-d assay (10-20 post-hatching). Average initial weight was $157 \mathrm{~g}$. \$ Data are means of three (assay 1) and four (assay 2) pens of four chicks during a 10-d assay (10-20 post-hatching). Average initial weight of chicks was 103 and 157 for assay 1 and 2, respectively. 

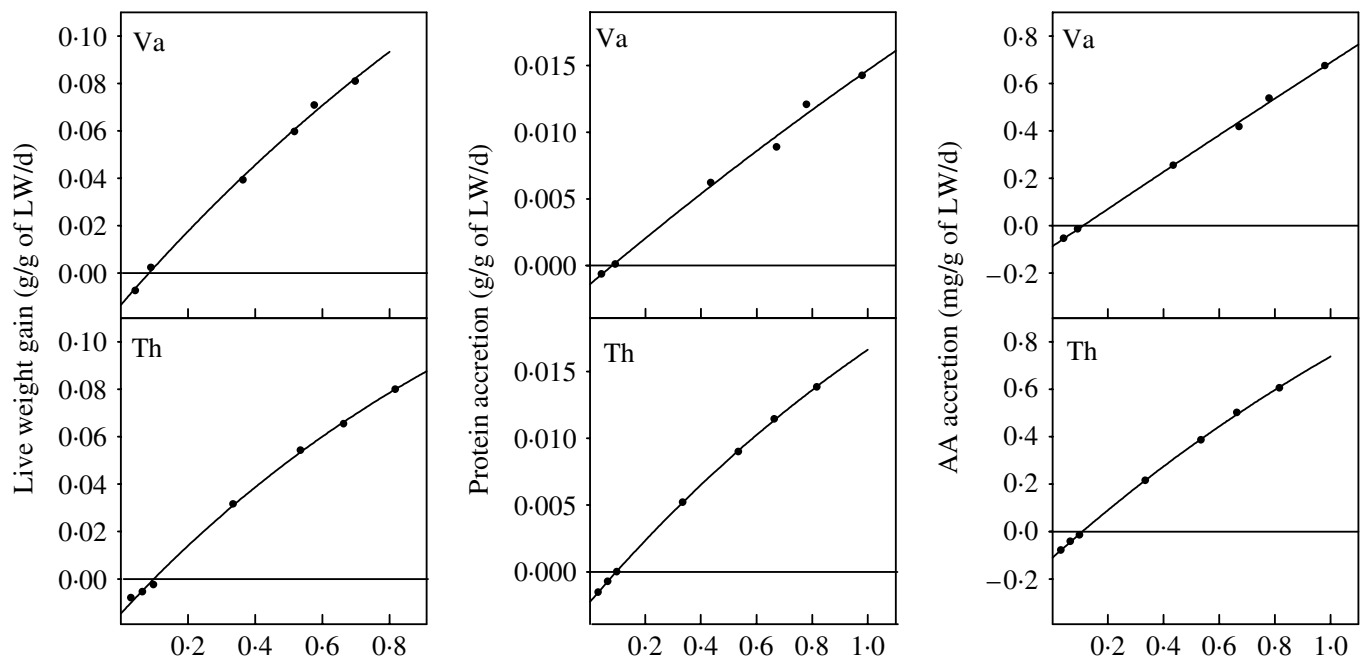

AA intake (mg/g LW/d)

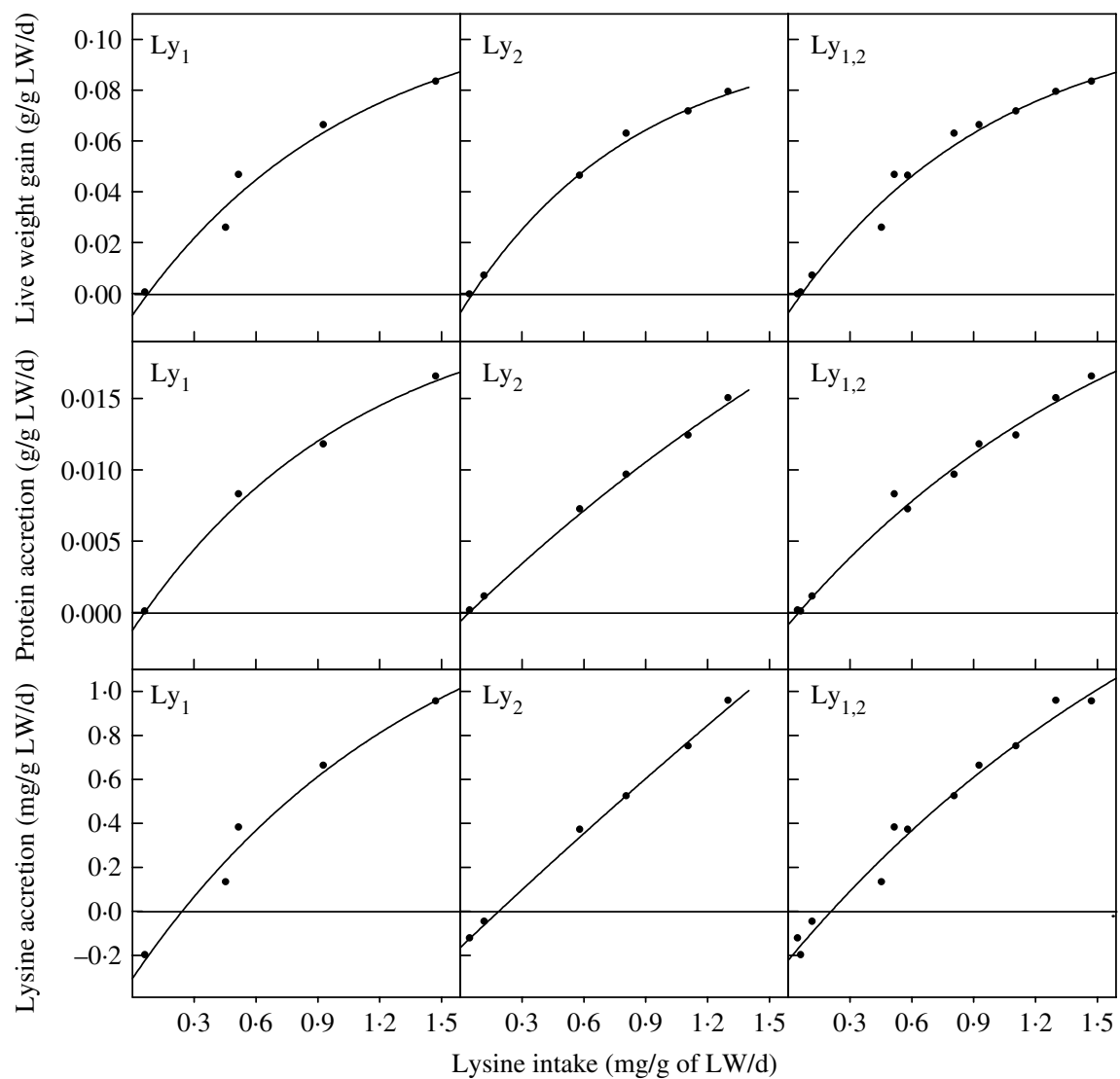

Fig. 1. Plots of LWG, protein and AA accretion against AA intake, showing fit of monomolecular equation to data. The AA were valine (Va), threonine (Th) and lysine (Ly). The data for Va were from Baker et al. (1996), Th from Edwards et al. (1997) and Ly from Edwards et al. (1999). For Ly, the numbers indicate fit of equation to data from assays 1 and 2, and pooled data (assays 1 and 2). 
Table 2. The maintenance requirements $\left(x_{m}\right)$ for individual AAs $(\mathrm{mg} / \mathrm{kg}$ of $\mathrm{BW} /$ day) obtained using the model together with reported values of maintenance requirements. S.E. are given in brackets

\begin{tabular}{|c|c|c|c|c|}
\hline AA & Data source* & $R^{2}$ & $x_{m}$ & $\begin{array}{c}\text { (Reference) } \dagger \text { values } \\
\text { Maintenance } \mathrm{mg} / \mathrm{kg} \text { of } \mathrm{BW} / \mathrm{d}\end{array}$ \\
\hline Valine & $\begin{array}{l}\text { (B), } \text { BWG }_{\text {zero }} \\
\text { (B), PA } \text { zero } \\
\text { (B), Val. A } A_{\text {zero }}\end{array}$ & $\begin{array}{l}99 \cdot 76 \\
99 \cdot 33 \\
99 \cdot 84\end{array}$ & $\begin{array}{l}84 \cdot 0(9 \cdot 63) \\
79 \cdot 6(25 \cdot 12) \\
111(11 \cdot 9)\end{array}$ & (F) 73, (M) 73, (W) 82 \\
\hline Threonine & $\begin{array}{l}\text { (E1), } \mathrm{BWG}_{\text {zero }} \\
\text { (E1), } \mathrm{PA}_{\text {zero }} \\
\text { (E1), Thr. } \mathrm{A}_{\text {zero }}\end{array}$ & $\begin{array}{l}99 \cdot 86 \\
99 \cdot 99 \\
99 \cdot 98\end{array}$ & $\begin{array}{c}98 \cdot 6(6 \cdot 14) \\
95 \cdot 9(1 \cdot 44) \\
109(2 \cdot 58)\end{array}$ & (F) 40, (M) 32, (W) 86 \\
\hline Lysine & 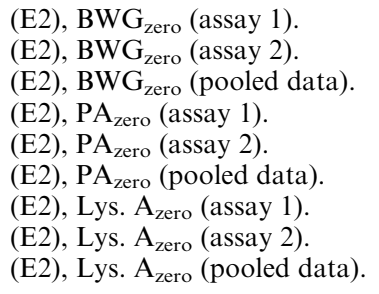 & $\begin{array}{l}96 \cdot 66 \\
99 \cdot 82 \\
98 \cdot 32 \\
99 \cdot 55 \\
99 \cdot 84 \\
98 \cdot 96 \\
97 \cdot 67 \\
99 \cdot 75 \\
98 \cdot 13\end{array}$ & $\begin{array}{l}77 \cdot 6(73 \cdot 62) \\
62 \cdot 5(11 \cdot 57) \\
67 \cdot 8(24 \cdot 23) \\
61 \cdot 2(39 \cdot 45) \\
45 \cdot 3(17 \cdot 80) \\
52 \cdot 2(26 \cdot 21) \\
242(51 \cdot 68) \\
187(18 \cdot 39) \\
209(26 \cdot 63)\end{array}$ & (F) 60, (M) 76, (W) 70 \\
\hline
\end{tabular}

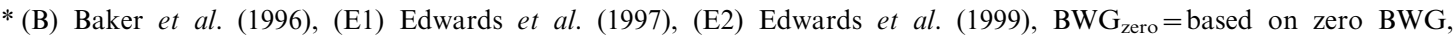
$\mathrm{PA}_{\text {zero }}=$ based on zero protein accretion, Val. $\mathrm{A}_{\text {zero }}=$ based on zero valine accretion, Thr. $\mathrm{A}_{\text {zero }}=$ based on zero threonine accretion and Lys. $\mathrm{A}_{\text {zero }}=$ based on zero lysine accretion.

$\dagger$ References: (F) Fisher (1998), (M) McDonald \& Morris (1985) and (W) Wiseman (1994).

Table 3. Parameter estimates obtained and growth indicators calculated from the monomolecular equation together with their reported values

Parameter estimates

\begin{tabular}{lcccccc}
\hline Data source & \multicolumn{1}{c}{$y_{\max }$} & $K$ & $x_{\max }$ & $R^{2}$ & - & - \\
\hline Lysine & $2 \cdot 34(1 \cdot 06)$ & $0.437(0 \cdot 243)$ & $209(26 \cdot 6)$ & $98 \cdot 13$ & - & - \\
Threonine & $2 \cdot 24(0 \cdot 36)$ & $0.449(0 \cdot 082)$ & $109(2 \cdot 6)$ & $99 \cdot 98$ & - & - \\
Valine & $17 \cdot 4(62 \cdot 8)$ & $0.045(0 \cdot 184)$ & $111(11 \cdot 9)$ & $99 \cdot 84$ & - & -
\end{tabular}

Growth indicators

\begin{tabular}{lccccccc}
\hline & $K y_{\max }{ }^{*}$ & $\bar{k}_{g}(1,2) \dagger$ & $\bar{k}_{g}(2,3) \dagger$ & $\bar{k}_{g}(2,4) \dagger$ & $\lambda_{g}+$ & $\begin{array}{c}{\left[0 \cdot 1 *\left(1 / \lambda_{g}\right)\right]^{\S}} \\
\text { Model }\end{array}$ & $\begin{array}{c}\text { References } \|(\text { values }) \\
\mathrm{g} / 100 \mathrm{~g} \text { protein }\end{array}$ \\
\hline Lysine & $1 \cdot 0$ & $0 \cdot 96$ & $0 \cdot 88$ & $0 \cdot 84$ & $0 \cdot 016$ & $6 \cdot 3$ & $\mathrm{E} 2(6), \mathrm{F}(7 \cdot 5), \mathrm{W}(6 \cdot 2)$ \\
Threonine & $1 \cdot 0$ & 0.98 & 0.93 & $0 \cdot 91$ & $0 \cdot 022$ & $4 \cdot 6$ & $\mathrm{E} 1(4 \cdot 35), \mathrm{F}(4 \cdot 2), \mathrm{W}(4 \cdot 2)$ \\
Valine & $0 \cdot 79$ & $0 \cdot 79$ & $0 \cdot 79$ & $0 \cdot 78$ & $0 \cdot 019$ & $5 \cdot 26$ & $\mathrm{~B}(4 \cdot 72), \mathrm{F}(4 \cdot 2), \mathrm{W}(4 \cdot 99)$ \\
\hline \hline
\end{tabular}

* The product $K y_{\max }$ is the maximum efficiency (mg of lysine, threonine or valine accretion/mg of lysine, threonine or valine intake) and occurs when $y$ equals zero (i.e. at maintenance).

$\uparrow$ Average efficiency of AA utilization for AA accretion (mg of AA accreted/mg of AA ingested) between 1-2, 2-3 and 2-4 $\times$ maintenance.

\$ Average efficiency of AA utilization for protein accretion between 1-4× maintenance ( $\mathrm{g}$ of protein accretion $/ \mathrm{mg}$ of AA).

$\S$ Average AA requirement for protein accretion between 1-4× maintenance ( $\mathrm{g}$ of AA/100 g of protein accretion).

|| Reported values of AA composition of the whole carcass of young chicken. (B) Baker et al. (1996), (E1) Edwards et al. (1997), (E2) Edwards et al. (1999), (F) Fisher (1998) and (W) Wiseman (1994).

Edwards et al. (1997, 1999) who stated that the maintenance requirement for a given AA depends on the response criterion being measured.
Indicators calculated from the monomolecular equation together with reported values of growth indicators are shown in Table 3. From values of $\bar{k}_{g}$ at 
different multiples of maintenance, it can be seen that efficiency of utilization of threonine and lysine is greatest at low intake levels and decreases as intake is increased.

\section{DISCUSSION}

Development of a more dynamic approach to determining AA requirements requires knowledge of digestibility of dietary protein, pattern of AA deposition, partial efficiency with which absorbed AAs (protein) are used for maintenance and deposition, and how metabolic modifiers alter rate of protein accretion and maintenance requirement (NRC 1994b). AA requirements of broilers have been determined using different methodologies, such as growth variables, carcass analysis, radioactive isotope studies, plasma AA analysis and rates of AA oxidation. However, the most common procedures are the evaluation of broiler performance as a function of graded levels of AA intake (the graded supplementation technique, D'Mello 1982), where a basal diet deficient in the test AA is progressively supplemented with increasing doses of the synthetic form of the test AA, and the summit dilution technique (Fisher \& Morris 1970), in which a summit diet with excessive amounts of all AAs but with the test AA first limiting is progressively diluted with either a non-protein diluent or a dilution feed with the balance of AAs reflecting that in the summit diet (Gous \& Morris 1985; Gous 2007). The concentration of an AA in the diet producing maximal $\mathrm{BW}$, highest feed conversion efficiency, etc. is determined as being requirement for the AA and is normally expressed as a fixed concentration of diet. These fixed values of AAs are compiled in tables of requirements and utilized for feed-cost formulation. With fixed requirements, it is impossible to predict the effect on rate of growth, feed intake, or carcass composition by manipulation of concentration and balance of dietary AAs. Furthermore, single fixed numbers for requirements are not useful for applying to an accurate cost-benefit analysis. Since responses of birds to dietary energy, protein and AAs are diminishing returns phenomena, they should be evaluated as such to estimate optimum economic levels, rather than as biological maxima (Clark et al. 1982; Gous \& Morris 1985). A linear or 'broken stick' method was used by Gous \& Morris (1985) to determine lysine requirement. Samadi \& Liebert (2008) applied the principles of the diet dilution technique using an exponential function for the modelling of lysine and threonine requirements in a stochastic manner. In the current study, a nonlinear deterministic model was used and an alternative simple method to estimate AA requirements in poultry was offered.

Darmani Kuhi et al. (2001, 2003, 2004) and Kebreab et al. (2008) developed a monomolecular equation to estimate energy and crude protein needed by growing broilers and turkeys for maintenance and gain. In the study presented here, the aim was to assess applicability of this model in estimating AA requirements for maintenance, gain and protein (or AA) accretion in fast- and slow-growing broiler strains fed crystalline AA diets with a wide range of dosing levels. With regard to the estimates of AA requirements for maintenance (Table 2) and average AA requirement for protein accretion between $1 \times$ and $4 \times$ maintenance (Table 3 ), it can be seen that these estimates lie in the range reported by different researchers. The estimated maintenance requirements for lysine are higher based on lysine accretion than on either BW gain or protein accretion, which are in agreement with the results of Edwards et al. (1999) who pointed out that the maintenance requirement estimates from zero lysine accretion were much higher than those obtained from zero protein accretion. According to Edwards et al. (1999) this reflects a shift in type of protein in the body, with more collagen protein and less contractile protein being present in chicks fed lysine levels near maintenance. They conclude that the lysine requirement for maintenance of broiler chicks is not low but instead is high. The maintenance requirements for AAs can be influenced by a multitude of factors such as different concentrations of dietary AA, response criteria (protein or AA accretion), environmental conditions and genetics. According to Leclercq (1998) and Vazquez \& Pesti (1997) the particular mathematical model being used to calculate AA requirement can also influence AA requirement profiles. With the current estimates of the maintenance requirements for lysine $(67 \cdot 5,52 \cdot 2$ and $209 \mathrm{mg} / \mathrm{kg}$ of $\mathrm{LW} / \mathrm{d}$ for zero $\mathrm{BW}$, protein and lysine accretion, respectively) together with the estimates of the total lysine requirements when growth rate, protein and lysine accretion reach their maximum values, the maintenance requirements for lysine represent $0.45,0.35$ and 0.13 of the total requirements which are in the range reported previously by researchers. A higher maintenance requirement for lysine as a percentage of total lysine requirements is in agreement with the result of Emmert \& Baker (1997), who pointed out that the use of lysine accretion as a criterion led to much larger estimates of maintenance requirement as a percentage of the total requirements. Additionally, an estimate of $6.3 \mathrm{~g}$ lysine for $100 \mathrm{~g}$ protein accretion and an efficiency of lysine utilization of $1 \cdot 0-0 \cdot 85$, which are both biologically meaningful, can be considered as further evidence of the predictive ability of the model.

Average efficiency of recovering AA in whole body protein, between maintenance and $4 \times$ maintenance, estimated by the model was $1.0-0.91$ for threonine, $1 \cdot 0-85$ for lysine and $0 \cdot 79-0.78$ for valine (Table 3 ), which is in agreement with values of $0.95-1.00$ reported by Harper et al. (1970) and Morris (1972) for 
efficiency of utilization of limiting AAs. These results are also in agreement with reported values of $0 \cdot 85-1 \cdot 0$ and $0.80-0.94$ achieved in growing pigs given semipurified diets and fed to optimum rates of growth (Whittemore 1983; NRC 1994b). Considering the values of $\bar{k}_{g}$ at different multiples of maintenance, the efficiency of utilization of threonine and lysine is greatest at low intake levels and decreases as intake is increased. These results are supported by conventional wisdom, namely that a gradual decrease in utilization of nutrients for producing gain occurs as intake increases. This is partly due to a slight fall in digestive efficiency of the animal with increased feeding level and partly to the fact that anabolic processes are less efficient than catabolic ones. Protein turnover is higher as protein intake is increased, as any excess in AA supply causes a rise in AA degradation rates (Riis 1983a,b). Therefore, successive increments of daily intake of nutrients result in progressively smaller increments in daily gain (Blaxter \& Boyne 1978).

In conclusion, results presented here and those previously reported for broilers and turkeys (Darmani Kuhi et al. 2001, 2003) and Kebreab et al. (2008) can be considered as a basis for accepting the general validity of the monomolecular equation to predict the magnitude and direction of responses of growing broilers and turkeys to dietary energy and protein (or AA) intake without making any initial assumptions.

\section{REFERENCES}

Baker, D. H. (1991). Partitioning nutrients for growth and other metabolic functions: efficiency and priority considerations. Poultry Science 70, 1797-1805.

Baker, D. H., Fernandez, S. R., Parsons, C. M., Edwards, H. M. III, Emmert, J. L. \& Webel, D. M. (1996). Maintenance requirement for valine and efficiency of its use above maintenance for accretion of whole body valine and protein in young chicks. Journal of Nutrition 126, $1844-1851$.

Baker, H. D., Batal, A. B., Parr, T. M., Augspurger, N. R. \& Parsons, C. M. (2002). Ideal ratio (relative to lysine) of tryptophan, threonine, isoleucine, and valine for chicks during the second and third weeks posthatch. Poultry Science 81, 485-494.

Blaxter, K. L. \& Boyne, A. W. (1978). The estimation of the nutritive value of feeds as energy sources for ruminants and the derivation of feeding systems. Journal of Agricultural Science, Cambridge 90, 47-68.

Boorman, K. N. \& Burgess, A. D. (1986). Responses to amino acids. In Nutrient Requirements of Poultry and Nutritional Research (Eds C. Fisher \& K. N. Boorman), pp. 99-123. London, UK: Butterworth.

Clark, F. A., Gous, R. M. \& Morris, T. R. (1982). Response of broiler-chickens to well-balanced protein mixtures. British Poultry Science 23, 433-446.

Curnow, R. N. (1973). A smooth population response curve based on an abrupt threshold and plateau model for individuals. Biometrics 29, 1-10.

Darmani Kuhi, H., Kebreab, E., Owen, E. \& France, J. (2001). Application of the law of diminishing returns to describing the relationship between metabolizable energy intake and growth rate in broilers. Journal of Animal and Feed Sciences 10, 661-670.

Darmani Kuhi, H., Kebreab, E., Lopez, S. \& France, J. (2003). A comparative evaluation of functions for the analysis of growth in male broilers. Journal of Agricultural Science, Cambridge 140, 451-459.

Darmani Kuhi, H., Kebreab, E., Lopez, S. \& France, J. (2004). A comparative evaluation of functions for describing the relationship between live-weight gain and metabolizable energy intake in turkeys. Journal of Agricultural Science, Cambridge 142, 691-695.
D'Mello, J. P. F. (1982). A comparison of two empirical methods of determining amino acid requirements. World's Poultry Science Journal 38, 114-119.

Edwards, H. M. III. \& BAKER, D. H. (1999). Maintenance sulfur amino acid requirements of young chicks and efficiency of their use for accretion of whole body sulfur amino acids and protein. Poultry Science 78, 1418-1423.

Edwards, H. M. III, Baker, D. H., Fernandez, S. R. \& Parsons, C. M. (1997). Maintenance threonine requirement and efficiency of its use for accretion of whole body threonine and protein in young chicks. British Journal of Nutrition 78, 111-119.

Edwards, H. M. III, Fernandez, S. R. \& Baker, D. H. (1999). Maintenance lysine requirement and efficiency of using lysine for accretion of whole-body lysine and protein in young chicks. Poultry Science 78, 1412-1417.

Emmans, G. C. (1981). A model of the growth and feed intake of ad libitum fed animals, particularly poultry. In Computers in Animal Production, Occasional Publication No. 5 (Eds G. M. Hillyer, C. T. Whittemore \& R. G. Gunn), pp. 103-110. Edinburgh: British Society of Animal Production.

EMmert, J. L. \& BAKer, D. H. (1997). Use of the ideal protein concept for precision formulation of amino acid levels in broiler diets. Journal of Applied Poultry Research 6, 462-470.

Fatufe, A. A. \& Rodehutscord, M. (2005). Growth, body composition, and marginal efficiency of methionine utilization are affected by nonessential amino acid supplementation in male broiler chicken. Poultry Science 84, 1584-1592.

Fatufe, A. A., Timmler, R. \& Rodehutscord, M. (2004). Response to lysine intake in composition of body weight gain and efficiency of lysine utilization of growing male chickens from two genotypes. Poultry Science 83, 1314 1324.

FISHER, C. (1998). Lysine: amino acid requirements of broiler breeders. Poultry Science 77, 124-133.

Fisher, C. \& Morris, T. R. (1970). The determination of the methionine requirement of laying pullets by a diet dilution technique. British Poultry Science 11, 67-82. 
Fisher, C., Morris, T. R. \& Jennings, R. C. (1973). A model for the description and prediction of the response of laying hens to amino acid intake. British Poultry Science 14, 469-484.

Gahl, M. J., Crenshaw, T. D. \& Benevenga, N. J. (1994). Diminishing returns in weight, nitrogen, and lysine gain of pigs fed six levels of lysine from three supplemental sources. Journal of Animal Science 72, 3177-3187.

Gous, R. M. (2007). Predicting nutrient responses in poultry: future challenges. Animal 1, 57-65.

Gous, R. M. \& Morris, T. R. (1985). Evaluation of a diet dilution technique for measuring the response of broiler chickens to increasing concentrations of lysine. British Poultry Science 26, 147-161.

Harper, A. E., Benevenga, N. J. \& Wohlhueter, R. M. (1970). Effects of ingestion of disproportionate amounts of amino acids. Physiological Review 50, 428-558.

Heger, J. \& Frydrych, Z. (1985). Efficiency of utilization of essential amino acids in growing rats at different levels of intake. British Journal of Nutrition 54, 499-508.

Hurwitz, S. D., Sklan, D. \& Bartov, I. (1978). New formal approaches to the determination of energy and amino acid requirements of chicks. Poultry Science 57, 197-205.

Hurwitz, S., Frisch, A., Bar, U., Eisner, I., Bengal, I. \& Pines, M. (1983). The amino acid requirements of growing turkeys. 1. Model construction and parameter estimation. Poultry Science 62, 2208-2217.

Kebreab, E., France, J., Darmani Kuhi, H. \& Lopez, S. (2008). A comparative evaluation of functions for partitioning nitrogen and amino acid intake between maintenance and growth in broilers. Journal of Agricultural Science, Cambridge, 146, 163-170.

LeClerCQ, B. (1998). Lysine: specific effects of lysine on broiler production: comparison with threonine and valine. Poultry Science 77, 118-123.

McDonald, M. W. \& Morris, T. R. (1985). Quantitative review of optimum amino acid intakes for young laying pullets. British Poultry Science 26, 253-264.

Morris, T. R. (1972). Prospects of improving the efficiency of nutrient utilization. In Egg Formation and Production (Eds B. M. Freeman \& P. E. LaKe), pp. 139-159. Edinburgh: British Poultry Science Ltd.
National Research Council (1994a). Nutrient Requirements of Poultry, 9th revised edition. Washington, DC: National Academy Press.

National Research Council (1994b). Metabolic Modifiers: Effects on the Nutrient Requirement of Food Producing Animals. Washington, DC: National Academy Press.

Oviedo-Rondón, E. O. \& Waldroup, P. W. (2002). Models to estimate amino acid requirements for broiler chickens: a review. International Journal of Poultry Science 1, 106113.

Pesti, G. M. \& Miller, B. R. (1997). Modelling for precision nutrition. Journal of Applied Poultry Research 6, 483-494.

RIIS, P. M. (1983a). Proteins. In Dynamic Biochemistry of Animal Production (World Animal Science A3) (Ed. P. M. Riis), pp. 75-108. Amsterdam, The Netherlands: Elsevier.

RIIS, P. M. (1983b). The pools of cellular nutrients: amino acids. In Dynamic Biochemistry of Animal Production (World Animal Science A3) (Ed. P. M. Riis), pp. 151-172. Amsterdam, The Netherlands: Elsevier.

SAmadi \& Liebert, F. (2007a). Lysine requirement of fast growing chickens - effects of age, sex, level of protein deposition and dietary lysine efficiency. The Journal of Poultry Science 44, 63-72.

SAmadi \& Liebert, F. (2007b). Threonine requirement of slow-growing male chickens depends on age and dietary efficiency of threonine utilization. Poultry Science 86, 1140-1148.

Samadi \& Liebert, F. (2008). Modelling the optimal lysine to threonine ratio in growing chickens depending on age and efficiency of dietary amino acid utilisation. British Poultry Science 49, 45-54.

SPSS (1998). SigmaPlot 5.0 User's Guide. Chicago: SPSS Inc.

Vazquez, M. \& Pesti, G. (1997). Estimation of the lysine requirement of broiler chicks for maximum body gain and feed efficiency. Journal of Applied Poultry Research 6 , 241-246.

Whittemore, C. T. (1983). Development of recommended energy and protein allowances for growing pigs. Agricultural Systems 11, 159-186.

Wiseman, J. (1994). Nutrition and Feeding of Poultry. Nottingham, UK: Nottingham University Press. 